\title{
IL34 wt Allele
}

National Cancer Institute

\section{Source}

National Cancer Institute. IL34 wt Allele. NCI Thesaurus. Code C122068.

Human IL34 wild-type allele is located in the vicinity of $16 q 22.1$ and is approximately $81 \mathrm{~kb}$ in length. This allele, which encodes interleukin-34 protein, is involved in cytokine receptor signaling. 